\title{
EXTINCTION OF THE OBLIGATION TO CONTRIBUTE TO TRADE UNIONS
}

\section{EXTINÇÃO DA OBRIGATORIEDADE DA CONTRIBUIÇÃO SINDICAL}

\section{GILBERTO STÜRMER}

Lawyer and Jurist, Sectional Adviser of OAB/RS (Brazilian Bar Association of the State Rio Grande do Sul) (2013/2015). Member of Instituto dos Advogados do Rio Grande do Sul - IARGS (Rio Grande do Sul Lawyers Institute). Bachelor's degree in Law from Pontifícia Universidade Católica do Rio Grande do Sul (Pontifical Catholic University of Rio Grande do Sul) (1989), Master's degree in Law from Pontifícia Universidade Católica do Rio Grande do Sul (2000), Doctor's Degree in Labor Law from Universidade Federal de Santa Catarina (Federal University of Santa Catarina) (2005) and a Postdoctoral degree in Law from Sevilla University (Spain) (2014). Coordinator of the Postgraduate Course - Specialization in Labor Law and Procedural Labor Law at Pontifícia Universidade Católica do Rio Grande do Sul. Coordinator of the Social Law Center of the Law School of Pontifícia Universidade Católica do Rio Grande do Sul. Full Professor of Labor Law in the Graduate and Postgraduate Courses (Specialization, Master's and Doctorate) at the same School. Holder of Chair No. 100 of the Brazilian Academy of Labor Law. Founder and holder of Chair No. 04 of the Sul-riograndense Academy of Labor Law. President of the Sul-riograndense Academy of Labor Law (2018/2020). Its main areas of activity are Individual Labor Law and Collective Labor Law, and as the main line of research, the Effectiveness of the Constitution and Fundamental Rights in Labor Law 


\section{ABSTRACT}

The article deals with the issue of union contribution from its creation and compulsory until the advent of Law 13467/2017, when it is no longer mandatory. The matter (extinction of the obligation) was taken to the Federal Supreme Court, which ruled on the constitutionality of the amendment.

KEYWORDS: Extinction of the Obligation of the Union Contribution; Freedom of Association; Labor Reform.

\section{RESUMO}

O artigo aborda o tema da contribuição sindical a partir da sua criação e compulsoriedade até o advento da Lei $\mathrm{n}$ - 13.467/2017, quando deixou de ser obrigatória. A matéria (extinção da obrigatoriedade) foi levada ao Supremo Tribunal Federal, que decidiu pela constitucionalidade da alteração.

PALAVRAS-CHAVE: Extinção da Obrigatoriedade da Contribuição Sindical; Liberdade Sindical; Reforma Trabalhista.

\section{INTRODUCTION}

After the proceedings in the House of Representatives and the Federal Senate, especially in the first half of 2017, Law No. 13,467, of July 13, 2017 was approved, sanctioned and published. The new law, a result of the so-called "Labor Reform", came into force 120 days after its publication, that is, November 11, 2017.

The Labor Law in Brazil was substantially altered, both in individual and collective relations - material law - and in procedural relations. 
The focus here is to briefly review, on a trial basis, the changes in relation to union contributions, in relation to the obligation of collecting it as well as about the position of the Federal Supreme Court on the subject, when they are provoked.

Inserted within the area of the author's research, the article covers the area that the Collective Labor Law acts in and the line of research that deals with the effectiveness of the Constitution and Fundamental Rights in Labor Law.

In regard to methodology used, this paper is a brief essay to comment on the chosen themes, exposing some ideas and critiques about them, presenting the author's initial point of view.

\section{A BRIEF HISTORY OF UNION CONTRIBUTIONS}

The union contribution, formerly known as the trade union tax, was created during the Estado Novo (New State) era. It is part of the common sources of funding, along with the assistance contribution, provided for in the collective bargaining instrument, the confederation contribution, provided for in the Constitution of the Republic, art. 8, IV, and must be approved by the assembly of the category, and finally, the associative contribution, as foreseen in the statute.

According to Nascimento (2005, p.262), "At the time of the control of the unions by the Estado Novo, the compulsory trade union tax - a name later changed to union contribution - was imposed, a type of tax, with which the State intended to provide a source of resources to the unions."

Established by the 1937 Constitution, until the enactment of Law No. $13,467 / 2017$, the union contributions were the main source of income for the union, consistent with the publicist design that inspired the corporatist union which gave the unions the power to impose contributions and exercise functions delegated by the Government (NASCIMENTO, 2005, p.262).

The constitutional command of 1937 was regulated by Decree-Law No. 1402 of 1939 , which included among the prerogatives of the trade unions, "to impose 
contributions on all those who participate in the professions or categories represented. Decree-Law No.2377 of 1940 then followed, which called it a union tax, setting the rates and payment dates, as a payroll deduction, the dates for the companies to collect and the division of percentages.

The rules were inserted in Decree-Law No. 5,452, of 1943, the Consolidation of Labor Laws, disciplined in articles 578 to 610.

On November 14, 1966, through Decree-Law No. 27, the name union tax was changed to union contribution. Decree-Law No. 229, of 1967, ratified the new denomination, which has been maintained until today (STRÜMER, 2007, p.89).

It is important to register Chiarelli's (2005, p.222) position on the legal nature of the union, for whom "the union would always remain - and will remain - as the fruit of the solidarity union of those who would have similar collective professional interests; interests that, while not being equal to the individual, continue to gravitate in the private system."

Bezerra Leite (2018, p.789) points out that Law $13467 / 1207$ has radically altered the tax nature of the union contributions, insofar as it ceased to be compulsory and became optional.

These changes will be examined in the next topic.

\section{CHANGES IN UNION CONTRIBUTIONS, RESULTING FROM LAW 13467/2017}

According to Martinez (2017, p.941):

[...] the union contribution was a compulsory financial support (until the effective date of Law No. 13.467 / 2017), of a para-fiscal nature, as foreseen in the final part of art. 8, IV, of the constitutional text and in articles 578 to 610 of the CLT, and imposed on all workers and employers simply because they belong to the professional or economic category.

Law No. 13467/2017, known as "Labor Reform", has substantially altered Labor Law, in the individual, collective and procedural areas. It is true that, before the 
labor reform, there should have been a trade union reform, thereby finally establishing freedom of association in Brazil. This, however, did not occur. The end of union unity (Article 8, II, of the Constitution of the Republic), depends on a constitutional amendment. The classification of trade unions by category should also be changed.

It is certain that the advent of freedom of association could and should be implemented by the entry of ILO Convention 87 into the Brazilian legal system. Article 5 , paragraph 3 of the Constitution, together with Constitutional Amendment No. $45 / 2004$, sates that human rights treaties that are approved by the House of Representatives and the Senate in two rounds, by three fifths of the votes of the respective members, be entered into the legal system with the status of constitutional amendment.

ILO Convention 87 defines "freedom of association" and it is therefore a human rights treaty.

See Articles 2 and 3 of the Convention:

Article 2. - Workers and employers, without distinction whatsoever, shall have the right to establish and, subject only to the rules of the organization concerned, to join organisations of their own choosing without previous authorization Article 3 - 1. Workers' and employers' organizations shall have the right to draw up their constitutions and rules, to elect their representatives in full freedom, to organize their administration and activities and to formulate their programmes. 2. The public authorities shall refrain from any interference which would restrict this right or impede the lawful exercise thereof.

Its final part is clear in stating that the public authorities must refrain from any interference which would restrict this right or impede the lawful exercise thereof.

Here we register the position of Perez Luño $(1990$, p.48) on the definition of human rights:

[...] a set of faculties and institutions that at every historical moment fulfill the requirements of human dignity, freedom and equality, which must be positively recognized by the legal systems at national and international levels $[\ldots]$ 
There is no doubt that ILO Convention 87 , which provides for freedom of association, is a human rights treaty.

What is lacking, unfortunately, is the political will to implant true freedom of association in Brazil.

As already mentioned, the changes resulting from Law 13467/1207 in the chapter dealing with union contributions, extinguished the obligation thereof.

Let us then see, if this is not the case:

The new wording of Article 545, a kind of "umbrella" of contributions, clearly establishes the obligation of the individual's authorization to be given to the interested parties for the payroll deduction of any contribution:

Article 545. Employers are obliged to deduct from their employees' payroll, once duly authorized by them, the contributions owed to the union, when notified by the union (not mentioned in the original).

With regard to trade union contributions, the need for individual authorization is also crystal clear:

Article 578. The contributions due to the trade unions by the participants of the economic or professional categories or the professions represented by these entities shall be paid, collected and applied in the manner established in this Chapter, provided they are previously and expressly authorized (not mentioned in the original). Article 579. The deduction of the union contribution is subject to the prior and express authorization of those who participate in a particular economic or professional category, or of a liberal profession, in favor of the representative trade union of the same category or profession or, in the absence of this, in conformity with the provisions of article 591 of this Consolidation (not mentioned in the original). Article 582. Employers are required to deduct from their employees' payroll in the month of March of each year the union contribution of employees who previously and expressly authorized the deduction for the respective unions (not mentioned in the original). Article 602. Employees who are not working during the month destined for the deduction of the union contribution and that previously and expressly authorized the deduction will have the amount deducted during the first month after they resume work (not mentioned in the original).

There is no doubt as to the scope sought by the legislature for the union contribution. 
If it is true that the union contribution has not been extinguished, it is no less certain that the deduction thereof depends on the previous and express individual authorization of the individual who intends to contribute.

Article $611-\mathrm{B}$ of the CLT, established by Law 13467/17, expressly provided:

Art. 611-B. Unlawful object of collective agreement or collective bargaining agreement, exclusively, the suppression or reduction of the following rights: [...] XXVI - freedom of association or professional association of the worker, including the right not to suffer, without express and prior consent, any collection or salary deduction established in a collective agreement or collective bargaining agreement (not mentioned in the original); [...]

Contrary to the general thesis that any assembly or collective regulation may decide on the deduction of any contribution from employers, employees, selfemployed or liberal professionals, the addition of Article 611-B to the CLT, providing rights that can not be subject to collective bargaining, item XXVI is clear in determining prior and express individual consent for deductions, including union contributions.

The alteration, the object of discussions and attacks since its validity, on November 11, 2017, was taken to the Federal Supreme Court.

\section{THE FEDERAL SUPREME COURT AND UNION CONTRIBUTIONS}

Several Direct Actions of Unconstitutionality were filed against the aforementioned changes in the trade union contributions material. All actions, including constitutionality, converged to the Direct Action of Unconstitutionality No. 5794-DF. Various trade union entities were claimants. The Rapporteur was Minister Edson Fachin.

Judged in plenary on 06/29/2018, the decision regarding ADI No. 5794-DF was as follows: The Court, by majority vote and in accordance with the vote of Minister Luiz Fux, who drafted the judgment, dismissed the claims formulated in the 
unconstitutionality and constitutionality direct actions. Ministers Edson Fachin (Rapporteur), Rosa Weber and Dias Toffoli were out voted. Ministers Celso de Mello, Ricardo Lewandowski and Luiz Fux were justifiably absent. The judgment was presided over by Minister Carmen Lúcia. Plenary, 06/29/2018.

Among the grounds of the final decision of the Federal Supreme Court, is that the Constitution does not oblige those represented to join, which would be incompatible with the mandatory contribution.

The question of the need for change by complementary law has already been surpassed.

At the time of drafting this text, the judgment, which was drafted under the responsibility of Minister Luiz Fux, had not yet been published ${ }^{1}$.

On the other hand, it is important to refer to Minister Fachin's arguments, and here he opposes them.

Let's see:

Argument 1: The measure would render the model of Brazilian trade unionism unrecognizable and contradictory, which was structured on three interdependent pillars, namely: a) union unity; b) mandatory representativeness; c) costing through a compulsory requirement of a tax nature (union contribution).

Counter-argument 1: It is true that in the Brazilian union system there are still other restrictions on freedom of association, such as union unity and the adoption of the category criterion. Nevertheless, the amendment of these forecasts requires a constitutional amendment, while the obligation of union contributions, being diverse, because of its infra-constitutional nature, can be carried out by means of a legislative change, that is, in the CLT, as was the case of Law 13467/17. Therefore, as you can see, you can not condition the elimination of the union contribution obligation to the modification of these other aspects related to the Brazilian trade union system.

Argument 2: By making the union contribution optional, workers would not feel inclined to voluntarily contribute to the trade unions of their respective professional categories, which substantially deinstitutionalizes the main source of 
funding for trade union institutions, weakens social rights with the reduction of the financing capacity of union activities, thereby making the trade union regime recognized as a fundamental right.

Counter-argument 2: It should be noted that the union contribution was not extinguished, nor has it left the trade union organizations without any possibility of obtaining financial resources for its activities, only its compulsory character was extinguished, signaling to the trade union entities the need of actions with effective representativeness for their permanence in the system. In addition, there are other forms of union contributions that have not been subject to change. Law No. 11.648 / 2008, which recognized the trade union Centers as an organ of the system and remitted part of the union contributions to these bodies, this provided for the creation of a negotiating contribution, which has not yet occurred. Article 8, IV, of the Constitution, final part, uses the term "contribution provided by law". It would be contradictory to read that a certain subject should be provided for by law and conclude that it would be forbidden for the legislator, under penalty of unconstitutionality, to seek to change by legal means the legal treatment given to the same subject. The weakening of social rights, on the contrary, is due to the absence of freedom of association, and the union contribution is one of the reasons for this absence.

Argument 3: With regard to the union contribution, the 1988 Constitution would have established a rule of differentiated tax jurisdiction, of cogent exercise, which supposedly would have established a fundamental and binding duty to the powers constituted to the tax obligation to maintain the union contribution, this would then prevent the legislature from revoking the compulsory nature of the exemption, without another institute being created to equalize the system.

Counter-argument 3: The compulsory trade union contribution, which has a tax nature, is in fact contrary not only to the principle of freedom of association, but also to the very essence of the Democratic State of Law, in establishing the cost of trade unions, which are private in nature, as well as trade union activities through

1 October 2018. 
recipes of a public nature, which is only admitted in undemocratic, authoritarian and corporatist regimes, in which the unions are controlled and dependent on the public power. On the other hand, contrary to the position in this respect, there has never been any mention, in the constitutional history of Brazil, of a tax jurisdiction that could be understood as a cogent exercise by the legislator, whether to create taxes or to reduce them or even extinguish them. It is therefore an unprecedented interpretative proposal, extravagant and not shared by a significant portion of the authors of Tax Law, which is why this proposal should be widely discussed by the different legal sectors before it could be used in the precautionary declaration of unconstitutionality of a law.

Argument 4: There would have been a formal disregard for the provisions of Article 113 of the ADCT, since Bill 6,786 / 2016, which caused a reduction in resources for trade unions, would not have been accompanied by a study of the budgetary and financial repercussions of this legislative change, which would generate the unconstitutionality of the law arising from this same project.

Counter-argument 4: The product of the debated collection is almost entirely destined to the union entities, the reason why they do not influence the composition of the federal budget, not having a negative financial impact neither on the Union, nor on the other members of the Federal Public Administration. The discussion is in regards to the $10 \%$ allocated to the Special Employment and Wage Account (FAT), already reduced by a law of doubtful constitutionality (Law 11.648 / 2008), object of ADI 4067, awaiting judgment in the STF. It is important to note that, although not extinguished, under Law 13467/17, the union contribution ceased to be of a tax nature, since it was no longer a compulsory service. The change in the legal nature of the trade union contribution, by ceasing to be compulsory, in accordance with the principle of freedom of association, does not mean in technical terms, the renunciation of income, which includes amnesty, remission, subsidy, presumed credit, granting of an exemption in a non-general manner, change of rate or modification in the calculation basis that implies a discriminated reduction of taxes or contributions (Article 14, paragraph 1, Complementary Law No. 101/2000). 
It should be noted that there are two arguments of a labor nature, rejected by this author, and two arguments of a tributary nature, for which the author of this text has relied on texts about the subject (GARCIA, 2018).

It is understood that the fundamental aspect to support the understanding that the union contribution can not be compulsory and that both the Legislative Power and the Judiciary have been successful, regarding individual freedom and freedom of association.

If Brazil still does not have freedom of association under the terms recommended by the ILO, the end of the compulsory union contribution is the opening of a door in order to move in this direction.

\section{CONCLUSION}

The present text, a brief essay on labor union contribution and labor reform, as well as the contribution to the text in honor of the thirtieth anniversary of the Constitution of the Federative Republic of Brazil of 1988, aims to establish a position on the defense of human rights and fundamental right of freedom, in particular freedom of association.

The union contribution, originally a trade union tax, was created in a period of exception, where corporatism was the basis of the union system. Union entities and the State came together for the purpose of controlling the system and classes.

After this, and especially during the period which a Constitution that gives primacy to fundamental rights was valid, it was no longer possible to maintain the union contribution obligation. Truly serious unions, which are concerned with the collective interest, will find ways to maintain themselves.

It is no longer possible, especially during the years in which the ILO Convention 87 celebrates its 80th anniversary (the ILO will complete one hundred years in 2019), that Brazil has not ratified this International Treaty, which is indisputably a human right. 
It is late but not too late that we can not move towards true freedom of association which will undoubtedly bring better results for the work and employment relationship. Modern Labor Law can not do without the union between social and economic. This is the path to follow.

\section{REFERÊNCIAS}

BEZERRA LEITE, Carlos Henrique. Curso de Direito do Trabalho. São Paulo: Saraiva, $9^{\mathrm{a}}$ ed., 2018.

CHIARELLI, Carlos Alerto. O Trabalho e o Sindicato - Evolução e Desafios. São Paulo: LTr, 2005.

FERREIRA NETO, Arthur Maria. Instituto de Estudos Tributários. (acesso em 05/06/2018).

GARCIA, Gustavo Filipe Barbosa. Conjur. (acesso em 02/06/2018).

MARTINEZ, Luciano. Curso de Direito do Trabalho. São Paulo: Saraiva, $8^{a}$ ed., 2017.

MARTINEZ, Luciano. Reforma Trabalhista - entenda o que mudou - CLT Comparada e Comentada. São Paulo: Saraiva, 2ª ed., 2018.

NASCIMENTO, Amauri Mascaro. Compêndio de Direito Sindical. São Paulo: Ltr, $4^{\mathrm{a}}$ ed., 2005.

PEREZ LUÑO, Antonio Enrique. Derechos Humanos, estado de Derecho y Constitución. $3^{\text {a }}$ ed. Madri: Teccnos, 1990.

STÜRMER, Gilberto. A liberdade sindical na Constituição da República Federativa do Brasil de 1988 e sua relação com a Convenção 87 da Organização Internacional do Trabalho. Porto Alegre: Livraria do Advogado Editora, 2007. 